\title{
Stem Cell Therapy for Ischaemic Stroke: Translation from Preclinical Studies to Clinical Treatment
}

\author{
Joyce S. Balami ${ }^{1}$, Rosemary A. Fricker ${ }^{2}$ and Ruoli Chen ${ }^{* 2}$ \\ ${ }^{I}$ Acute Stroke Programme, Department of Medicine and Clinical Geratology, Oxford University Hospitals NHS Trust, \\ Oxford, UK \\ ${ }^{2}$ Institute for Science and Technology in Medicine, School of Medicine, Keele University, Staffordshire, UK
}

\begin{abstract}
No pharmacological intervention has been shown convincingly to improve neurological outcome in stroke patients after the brain tissue is infarcted. While conventional therapeutic strategies focus on preventing brain damage, stem cell treatment has the potential to repair the injured brain tissue. Stem cells not only produce a source of trophic molecules to minimize brain damage caused by ischaemia/reperfusion and promote recovery, but also potentially turn to new cells to replace those lost in ischaemic core. Although preclinical studies have shown promise, stem cell therapy for stroke treatment in human is still at an early stage and it is difficult to draw conclusions from current clinical trials about the efficacy of the different treatments used in humans. This article reviews the potential of various types of stem cells, from embryonic to adult to induced pluripotent stem cells, in stroke therapy, highlights new evidence from the ongoing clinical trials and discusses some of the problems associated with translating stem cell technology to a clinical therapy for stroke.
\end{abstract}

Keywords: Stroke, stem cells, endogenous, exogenous, pre-clinical studies, clinical trials.

\section{INTRODUCTION}

Despite recent advances in the diagnosis and treatment of acute stroke over the past two decades, stroke remains the third most common single cause of death in most parts of the developed world after ischaemic heart disease and neoplastic disease and the single leading cause of disability globally [1, 2]. Current treatment for stroke, particularly thrombolytic therapy when given in the acute phase of ischaemic stroke improves outcomes, both in survival and residual disability [3]. However, despite the significant clinical benefit, only a minority of eligible patients receive thrombolytic treatment because it must be administered within about $4.5 \mathrm{hrs}$ of stroke onset [4].

Once the brain tissue has been infarcted, further wellestablished treatments including the use of aspirin and management on stroke units are used to prevent stroke recurrence and other complications, as well as to prepare patients for rehabilitation therapy [5-8]. The greatest impact of stroke is attributable to impairment of neurological functions [8]. These neurological deficits are greatest in the acute phase and generally show fairly rapid recovery over the first 4 to 6 weeks after stroke, followed by more gradual improvement for up to one year after stroke [8-11]. Although most patients show some spontaneous recovery after a stroke, which can be further improved by rehabilitation therapy, many patients are still left with neurological deficits that result in significant chronic disability [8].

*Address correspondence to this author at the Institute for Science and Technology in Medicine, School of Pharmacy, Keele University, Staffordshire, ST5 5BG, UK; Tel: (44)1782733849; Fax: (44)1782733326; E-mail: ruolichen@gmail.com
Until recently, adult brain cells were thought to be unable to regenerate after sustaining damage. However, in the last decade evidence has shown that neurons and astrocytes can be generated from isolated cells of the adult mammalian central nervous system (CNS) [12] and regeneration has been demonstrated in the dentate nucleus of the hippocampus and in the sub-ventricular zone of the human adult brain $[13,14]$. The evidence for neurogenesis in the ischaemic penumbra in stroke patients has been shown, where the cells were found localized to the vicinity of blood vessels [15]. However, the capacity of neuronal replacement in the adult CNS is very low, with estimations between 0.2 and $10 \%$ of the lost neurons [16-18]. Several factors which can increase adult neurogenesis by stimulating formation or improving survival of new neurons, such as, erythropoietin, brain derived neurotrophic factor (BDNF), epidermal growth factor (EGF), etc, have been investigated into clinical usage for stroke treatment (see below) [19].

On the other hand, exogenous stem cell therapy has been explored as a treatment for various haematological diseases, vascular diseases (e.g. ischaemic heart disease and peripheral vascular disease) and neurological conditions (e.g. Parkinson's disease (PD), Huntington's disease, Alzheimer's disease, epilepsy, spinal cord injury). The most promising results have been obtained in treating $\mathrm{PD}$, with encouraging findings in treatment of Huntington's disease [20]. Compared to PD, where most prominent symptoms result from involvement of a specific (nigrostriatal doperminergic) neuronal type, in stroke all tissue elements are injured, and the damage caused by stroke may disrupt various anatomical pathways that must be restored for full recovery [21]. While conventional therapeutic strategies focus on preventing brain damage, stem cell treatment has the potential to repair the injured brain tissue. 
A growing number of experimental studies have shown that stem cell therapy can improve stroke recovery, however the mechanisms responsible for this remain a matter of considerable debate. It has been proposed that stem cell treatment induces a combined action via multiple cellular and molecular mechanisms to affect neurorestoration and neuroprotection rather than just a single mechanism [22, 23], and different cell type studied may have different mechanisms [24]. Stem cell treatment has shown to have various neuroprotective effects [25], including reductions in apoptosis [26, 27], inflammation [24, 28-30], and demyelination, as well as increased astrocyte survival rates [31-33] and enhanced structural plasticity \& axonal transport in the ischaemic brain [34]. Stem cell treatment also appears to improve the control of cerebral blood flow and bloodbrain barrier permeability $[24,35,36]$, as well as the activation of endogenous neuroprotection and neurorestoration pathways by the release of cytokines and trophic factors [19, 37-39]. It has been suggested the combination of improved neurogenesis, angiogenesis and synaptogenesis may lead to a more significant functional improvement in damaged areas as a result of stem cell treatment $[32,40,41]$. In addition to such neuroprotective and neurorestorative functions, stem cells have the capacity to self-renew and differentiate into different cell types, including neurons, astrocytes, and endothelial cells, which could replace the injured brain tissue and integrate into existing neural networks [42, 43]. However, both survival rate and differentiation rate of new-born or transplanted cells are low and therefore the contribution of stem cell integration to functional recovery is unclear after ischemic stroke [44].

\section{TYPES OF STEM CELLS-BASED THERAPIES}

Stem cell therapy in stroke patients can be broadly divided into endogenous and exogenous approaches $[45,46]$. While the endogenous approach aims at activating already existing stem cells within the patient, the exogenous approach involves the transplantation of stem cells into the patient (Table 1) [45, 46].
This review includes clinical trials for both endogenous and exogenous approaches.

\section{ENDOGENOUS APPROACH}

The endogenous approach to stem cell based therapy in stroke aims at stimulating host stem cells to promote angiogenesis and neurogenesis, re-innervating the damaged brain and correcting neurologic impairments. Mobilizing the host stem cells has numerous advantages over cell transplantation. The endogenous approach is less cumbersome, free of the logistical and ethical complexities associated with the use of embryonic or non-embryonic stem cells, avoids problems of graft rejection or uncontrolled graft cell proliferation and tumor formation, and does not require immunosuppression [47].

\section{Preclinical Studies}

Strategies which augment post-stroke angiogenesis and neurogenesis and neuroblast migration to the injured brain regions can result in rapid functional recovery and reduced infarct size [48]. Exogenous administration or genetic overexpression of growth factors such as granulocyte-colonystimulating factor (G-CSF), BDNF, vascular endothelial growth factor (VEGF), insulin like growth factor (IGF), epidermal growth factor (EGF), have been shown to increase post-stroke subventricular zone stem cell proliferation in rodents [49]. Since G-CSF is the only approved agent (see below), the review is limited to the discussion of studies involving this agent. G-CSF is a secreted $20 \mathrm{kD}$ growth factor that is responsible for the mobilization and maturation of bone marrow derived cells, resulting in the generation of mature neutrophilic granulocytes [50]. G-CSF can be released by neurones in response to cerebral ischaemia [51], while neurons themselves express the G-CSF receptor [52]. Administration of G-CSF mobilizes stem and progenitor cells from the bone marrow into the peripheral blood, which could then help with brain repair processes after stroke [5356]. Although G-CSF is able to stimulate haematopoietic CD34+ stem cells from bone marrow to peripheral blood, it is not really clear if the effects of G-CSF are mediated by the

Table 1. Stem Cell Types Proposed for Cell Replacement in the Human CNS

\begin{tabular}{|c|c|c|}
\hline Source & Advantage & Disadvantage \\
\hline Endogenous stem cells [47] & Multimodal activity (neuroprotective and neurogenic effects) & $\begin{array}{l}\text { Potential harmful effects of G-CSF induced } \\
\text { leukocytosis }\end{array}$ \\
\hline \multicolumn{3}{|l|}{ Exogenous stem cells } \\
\hline $\begin{array}{l}\text { NPC/NSC } \\
\text { Adult brain-derived NPC [68-70] } \\
\text { ES-derived NPC }[71-73,84,86] \\
\text { Foetal tissue-derived NPC }[87]\end{array}$ & $\begin{array}{l}\text { Potential to differentiate into neurons, astrocytes } \\
\text { and oligodendrocytes, which is helpful as all three } \\
\text { cell types are damaged following stroke }\end{array}$ & $\begin{array}{l}\text { Unable to differentiate efficiently, } \\
\text { particularly into specific neuronal phenotypes }\end{array}$ \\
\hline $\begin{array}{l}\text { Cell lines } \\
\text { NT2N cells [92] }\end{array}$ & Potential for unlimited expansion & Risk of malignant transformation \\
\hline Human Bone marrow cells $[102,105]$ & $\begin{array}{l}\text { Ideal for autologous (precluding the need for } \\
\text { immunosuppression) and allogenic use }\end{array}$ & $\begin{array}{l}\text { Poor survival when injected, due to either } \\
\text { lack of trophic support or through triggering } \\
\text { the inner immune system }\end{array}$ \\
\hline iPS cells $[131,132]$ & $\begin{array}{l}\text { Ideal for autologous (precluding the need for } \\
\text { immunosuppression) }\end{array}$ & Risk of malignant transformation \\
\hline
\end{tabular}


mobilized CD34+ stem cells. G-CSF exhibits neuroprotective and regenerative activity after stroke by mechanisms that include recruiting neural progenitor cells, reducing cerebral oedema, improving cell survival, and enhancing sensorimotor and functional recovery [51-56]. This multipotency makes G-CSF a suitable agent for stem cell based therapy in neurological diseases or injuries associated with complicated disruptions in neural circuitry, particularly stroke, where all tissue elements are damaged [47].

\section{Clinical Studies}

Currently, only G-CSF has received Food and Drug Administration (FDA) approval among the many potential stem cell mobilizing agents. The use of G-CSF has been shown to be safe in phase 1 clinical trials when used in acute ischaemic stroke (within 7 days) [57, 58]. Neurological function was improved, and G-CSF was well tolerated, with no severe adverse effects being reported other than bone pain and headache, which were tolerated by the patients $[57,58]$. However, G-CSF may induce a transient hypercoagulable state, as some patients receiving G-CSF developed acute arterial thrombosis $[59,60]$. G-CSF has also been used in the subacute phase (7-30days post-stroke), in the Stem Cell Trial of Recovery EnhanceMent After Stroke (STEMS). In this study G-CSF was shown to be effective at mobilizing bone marrow $\mathrm{CD} 34^{+}$stem cells into the peripheral bloodstream as well as being safe and well tolerated however no statistically significant neurological function improvement was observed [61]. This has led to STEMS II, a phase II trial which aims to further assess the safety of G-CSF. STEMS II has already recruited the targeted number of patients (60) and is currently in the follow-up phase [62]. Similarly, another phase II trial, $A x 200$ (G-CSF) for the treatment of ischemic stroke (AXIS), showed with 44 patients that G-CSF was well tolerated even at higher doses in patients with acute ischaemic stroke [63]. There were no observed thromboembolic events or related serious adverse effects in the active treatment group. Based on the results from AXIS, a large phase II trial [AXIS -2] is currently underway to confirm the safety and efficacy of intravenous G-CSF in a larger number [328] of patients with ischaemic stroke [64]. The Granulocyte-Colony Stimulating Factor In Ischemic Stroke (GIST) study, another phase 1 randomized double blind trial to determine the effect of the drug neupogen on stroke recovery is currently on-going [65].

Table 2 summarizes both the completed and on-going trials using endogenous stem cell therapies in stroke.

\section{EXOGENOUS APPROACH}

In the exogenous approach to stem cell based therapy, one of several human cell types is transplanted into a stroke patient, either systematically (intravenous) or locally (direct intracerebral transplantation).

Examples of such cell types include neural stem/progenitor cells, immortalized cell lines and bonemarrow-derived stem cells [66]. Exogenous stem cell based therapy may involve in vitro culture of cells for the expansion of cells numbers prior to administration [67].

\section{Neural Progenitor Cells (NPCs)}

NPCs can be derived from either adult brain [68-70] or embryonic/fetal tissues [71-73]. Both embryonic stem cell (ES)-derived and fetal-derived NPCs have the potential to develop into neurons, astrocytes or oligodendrocytes, which might be advantageous given that stroke injury damages all three-cell types [66, 69, 70]. ES cells can propagate in culture over many passages providing a virtually unlimited

Table 2. Complete and On-Going Clinical Trials of Endogenous Stem Cell Therapy

\begin{tabular}{|c|c|c|c|c|c|c|c|c|c|}
\hline Study & Study Design & Stroke Type & $\begin{array}{c}\text { Stroke } \\
\text { Location }\end{array}$ & $\begin{array}{l}\text { No. of } \\
\text { Patients }\end{array}$ & $\begin{array}{l}\text { Timing of } \\
\text { Delivery }\end{array}$ & $\begin{array}{l}\text { Route of } \\
\text { Delivery }\end{array}$ & $\begin{array}{c}\text { Trial } \\
\text { Outcome }\end{array}$ & Trial Status & Country \\
\hline $\begin{array}{l}\text { Schabitz et al., } \\
2010[63]\end{array}$ & $\begin{array}{c}\text { Phase II } \\
\text { R, DB }\end{array}$ & $\begin{array}{l}\text { Ischaemic } \\
\text { stroke }\end{array}$ & MCA-T & 42 & 12 hours & IV & $\begin{array}{l}\text { Safe and well } \\
\text { tolerated }\end{array}$ & completed & Germany \\
\hline $\begin{array}{c}\text { Sprigg et al., } \\
2006[61]\end{array}$ & $\begin{array}{c}\text { Phase II } \\
\text { R, DB, DE, PC }\end{array}$ & $\begin{array}{l}\text { Ischaemic } \\
\text { stroke }\end{array}$ & MCA-T & 36 & $\begin{array}{l}7 \text { to } 30 \\
\text { days }\end{array}$ & $\mathrm{SC}$ & $\begin{array}{l}\text { Safe and } \\
\text { tolerated }\end{array}$ & completed & UK \\
\hline $\begin{array}{l}\text { Shyu et al., } \\
2006 \text { [57] }\end{array}$ & $\begin{array}{l}\text { Phase I } \\
\text { R, BC }\end{array}$ & $\begin{array}{l}\text { Ischaemic } \\
\text { stroke }\end{array}$ & MCA-T & 10 & 7 days & $\mathrm{SC}$ & $\begin{array}{l}\text { Safe, with } \\
\text { improved } \\
\text { function }\end{array}$ & completed & Taiwan \\
\hline $\begin{array}{l}\text { Zhang et al., } \\
2006[58]\end{array}$ & $\begin{array}{c}\text { Phase I } \\
\text { R }\end{array}$ & $\begin{array}{l}\text { Ischaemic } \\
\text { stroke }\end{array}$ & MCA-T & 45 & 7 days & & $\begin{array}{l}\text { Safe, with } \\
\text { improved } \\
\text { function }\end{array}$ & completed & China \\
\hline $\begin{array}{c}\text { NCT00809549 } \\
{[65]}\end{array}$ & $\begin{array}{l}\text { Phase I } \\
\text { R, DB }\end{array}$ & $\begin{array}{l}\text { Ischaemic } \\
\text { stroke }\end{array}$ & $\begin{array}{l}\text { MCA-T } \\
\text { (PACS) }\end{array}$ & 20 & $\begin{array}{c}3 \text { to } 10 \\
\text { days }\end{array}$ & $\mathrm{SC}$ & $\begin{array}{l}\text { Safety and } \\
\text { efficacy }\end{array}$ & On-going & Canada \\
\hline $\begin{array}{c}\text { ISRCTN00927 } \\
836[64]\end{array}$ & $\begin{array}{c}\text { Phase II } \\
\text { R, TB, PC }\end{array}$ & $\begin{array}{c}\text { Ischaemic \& } \\
\text { haemorrhagic } \\
\text { stroke }\end{array}$ & $\begin{array}{c}\text { Cortical or } \\
\text { lacunar }\end{array}$ & 60 & $\begin{array}{c}3 \text { to } 30 \\
\text { days }\end{array}$ & $\mathrm{SC}$ & Safety study & $\begin{array}{l}\text { In the } \\
\text { following-up }\end{array}$ & UK \\
\hline $\begin{array}{c}\text { NCT00927836 } \\
{[64]}\end{array}$ & $\begin{array}{c}\text { Phase II } \\
\text { R, DB, MC, PC }\end{array}$ & $\begin{array}{l}\text { Ischaemic } \\
\text { stroke }\end{array}$ & MCA-T & 328 & 9 hours & IV & $\begin{array}{l}\text { Safety and } \\
\text { tolerability }\end{array}$ & On-going & Europe \\
\hline
\end{tabular}

$\mathrm{R}=$ Randomised, $\mathrm{PC}$ - Placebo controlled, $\mathrm{DE}=$ dose escalating, $\mathrm{BC}=\mathrm{Blinded}$ controlled, $\mathrm{TB}=$ Triple Blinded, $\mathrm{MC}=\mathrm{Multicentre}, \mathrm{MCA}-\mathrm{T}=\mathrm{Middle}$ cerebral artery territory, $\mathrm{PACS}=$ Partial anterior circulation stroke, $\mathrm{IV}=$ Intravenous, $\mathrm{SC}=$ subcutaneous 
supply of NPCs, however ES cells can be tumorigenic and therefore ES-derived NPCs may not be useful clinically unless removal of all residual ES cells could be guaranteed [74]. Compared to ES cells, fetal-derived NPCs have less potential of tumorigenicity as well as in vitro expansion [66].

\section{Preclinical Studies}

NPC transplantation into mice with collagenase-induced intracerebral haemorrhage [75], or into rats with middle cerebral artery occlusion (MCAO) [24, 34, 76], led to improved functional recovery and increased overall cell survival. The NPCs are mainly found in the perilesional area when injected systemically in MCAO mice, where they maintain an undifferentiated phenotype [77, 78], while grafted NPCs migrated to the haemorrhage core and also to the border of the lesion when given after collagenaseinduced intracerebral haemorrhage, differentiating mostly into astrocytes and to a lower extent into neurons [79, 80]. Interestingly, NPCs expressed BDNF, glial cell line derived neurotrophic factor (GDNF), fibroblast growth factor 2 (FGF-2), VEGF, hepatocyte growth factor (HGF) and IGF, providing evidence that some of the protective effects were likely mediated by a combination of neurotrophic support $[24,79,80]$. Mouse and human NPCs share the expression of a variety of functional immune-like receptors [81] and have been shown to inhibit $\mathrm{T}$ cell activation and proliferation [82]. Transplanted NPCs skewed the inflammatory infiltrate of the injured spinal cord, in turn promoting the healing of the injured cord [83]. Similarly, murine ES cells were able to migrate and differentiate into neurons in the border zone of the lesion of rat brains following MCAO and improve the functional recovery as well as reducing the infarct volume [84-87], while in the homologous mouse brain these cells did not migrate, but produced highly malignant teratocarcinomas at the site of implantation [84]. It was suggested that transplantation should be avoided at the early stage of cerebral ischaemia as the formation of teratomas was limited to the ischaemia environment [88].

\section{Clinical Studies}

The Pilot Investigation of Stem Cells in Stroke study (PISCES), a Phase I non-randomized, uncontrolled safety trial of manufactured (fetal derived) neural stem cells (CTX cells), to be delivered by stereotactic injection in patients with ischaemic stroke has recently commenced [89]. The ReNeuron CTX cells are conditionally immortalized as they contain an inducible cMyc gene. In the presence of tamoxifen cMyc is expressed and the cells grow extensively, this can be shut off by removing tamoxifen from the media [90]. This strategy appears to be successful as no tumours have been reported to date and ReNeuron have been given permission to go to the next step of their clinical trial (www.reneuron.com).

\section{NT2 Cell Lines}

NT2 is a teratocarcinoma cell line that can be differentiated to post-mitotic neuron-like cells (NT2N) with treatment of retinoic acid [91]. NT2N cells are post-mitotic, terminally differentiated and express morphological and molecular neuronal markers [92]. Being immortalized, these cells have the advantage of potentially unlimited expansion in culture as well as relative ease of preparation and longterm maintenance. However, the disadvantages in their use are the risk of malignant transformation of immortalized cells and their potential divergence from neural stem/progenitor cells over time, which has been shown to occur in culture [67].

\section{Preclinical Studies}

NT2N cells have been shown to significantly improve functional and cognitive deficits when transplanted into adult rats 4 weeks after MCAO [93]. After experimental stroke, animals that received a transplant of NT2N cells showed a significant $12-25 \%$ improvement in behavioral performance as well as a $25 \%$ reduction in ischaemic cell loss in the striatal penumbra compared to control stroke animals that received vehicle infusion alone [94-96].

\section{Clinical Studies}

In 1998, the FDA approved the first clinical trial of NT2N cell transplantation in stroke patients.

The phase I open-label clinical trial involved transplantation of cultured human NT2N cells into 12 patients with basal ganglia stroke along with an immunosuppressive regimen using cyclosporine-A for 8 weeks post-transplantation. The trial demonstrated a trend towards improved functional outcome in four patients [97]. No cell-related serious adverse events or deaths attributed to the neuronal cell implantation were reported during a 12month follow up [97]. Autopsy of the only patient who died (myocardial infarction 27 months post-transplantation) revealed survival of NT2N cells in the brain with some evidence that these cells had neuronal identities, and that the grafted cells had caused no injurious effects or inflammation and no evidence of tumour formation [98]. A subsequent Phase II study, which included 18 patients with either ischaemic or haemorrhagic stroke, demonstrated the safety and feasibility of neuronal cell transplantation for stroke patients. Although some patients (6 of the 14 transplanted patients) showed improvement in functional outcome as measured by a standardized stroke scale, this was not statistically significant [99]. Similar to the phase I trial, no cell-related adverse effects were reported and no signs of tumorigenicity were found with NT2N cellular transplantation after a 2 year follow-up in stroke patients. A Phase II randomized controlled trial demonstrated some improvements in cognitive function after neuronal cell transplantation as a treatment for basal ganglia stroke [100]. In spite of these promising results using of NT2N cells in patients with ischaemic stroke, there remains a need for further feasibility studies with a larger number of patients in the acute stroke setting.

\section{Bone-Marrow-Derived Stem Cells (BMSCs)}

BMSC give rise to a variety of hematopoietic lineages and repopulate the blood throughout adult life. Transplanted adult bone marrow cells have been shown to migrate into the brain in mice and differentiate into cells that express neuronspecific markers [101]. However, it has been suggested that some induction methods produce cells with neuronal properties but that are not true neurons [102]. Indeed there is now wide agreement that transdifferentiation does not occur 
[103], and evidence to suggest that neuronal phenotypes in vivo represent fusion of BMSCs with host cells [104, 105]. $\mathrm{BMSC}$ are ideal for autologous administration thus avoiding the need for immunosuppression as well as allogenic use. Similarly, their use is free of the ethical issues associated with destruction of embryos to produce embryonic- and fetal-derived cells [66].

\section{Preclinical Studies}

Much of the preclinical work examining the use of haematopoietic stem cells (HSCs) for stroke therapy has focused on potential mechanisms of functional recovery. $\mathrm{CD} 34^{+}$bone marrow-derived cells include populations of haematopoietic and endothelial stem cell and progenitor cells. Transplantation of $\mathrm{CD} 34^{+}$cells has been shown to increase angiogenesis in penumbral tissue following stroke $[106,107]$. However, the application of HSCs is hindered by their expandability, as cell dose is a major determinant of survival after HSC transplantation [108]. Further characterisation of hemangioblasts will be critical for a better understanding of the molecular events involved in their stem cell properties, as well as for using this cell population for clinical applications.

In addition to HSCs, bone marrow contains mesenchymal stem cells (MSCs) which have been found to possess the capacity for self-renewal and multi-lineage potential [109111]. The minimum criteria for defining MSCs have been defined as bone marrow cells that are plastic adherent under standard culture conditions, express CD105, CD73 and CD90, but lack expression of CD45, CD34, CD14, CD11b, CD79, CD19 and HLA-DR and are able to differentiate into osteoblasts, chondroblasts, and adipocytes in vitro [112]. MSCs are probably the most widely studied cells in experimental models of neurotransplantation after ischaemic stroke. Transplantation of MSCs one day after ischaemia can improve functional recovery after MCAO in rats [113-115]. In addition, delayed delivery of MSCs, even up to one month after ischaemia, can improve long-term functional outcome [116]. However, after transplantation, very few MSC cells are actually found in the brain and even fewer of these cells express neuronal markers [117]. Therefore, it is thought that neuroprotective mechanisms, such as the secretion of growth factors, promotion of angiogenesis and inflammatory modulation, are responsible for the observed therapeutic effects. Nevertheless, despite possible confounding effects, the emerging picture is of an intertwined relationship between neurogenesis and angiogenesis which may be mutually supportive [118].

\section{Clinical Studies}

Based on preclinical studies using HSCs for stroke therapy and in particular the role of $\mathrm{CD} 34^{+}$cells in angiogenesis-mediated neural plasticity post stroke, a number of clinical trials have been done using $\mathrm{CD} 34^{+}$ progenitor cells. A phase I clinical trial has demonstrated that transplantation of $\mathrm{CD} 34^{+}$progenitor cells is safe and beneficial for stroke recovery. The $\mathrm{CD} 34^{+}$progenitor cells used in this trial were obtained from peripheral blood of patients with strokes occurring within the past 6 to 60 months [119]. The encouraging findings from phase I has led to, a phase II trial, which is currently on-going to determine the potential efficacy of $\mathrm{CD} 34^{+}$cell implantation in chronic stroke [120]. Two clinical studies are also underway investigating the role of autologous $\mathrm{HSCs}\left(\mathrm{CD} 34^{+}\right.$cells $)$ transplantation in acute ischaemic stroke patients (Table 3) $[121,122]$.

The encouraging results from animal studies, which demonstrated that MSCs improve functional recovery post stroke, led to the first clinical trial using autologous, expanded MSCs in 5 patients with established ischaemic stroke ( $>1$ month post-infarct). This phase I/II clinical trial demonstrated the safety of intravenous administration of autologous expanded MSCs in stroke patients during a shortterm follow-up period. The results of the study also showed a (statistically non-significant) functional improvement in treated patients up to 1 year follow-up. There was no reported immediate or delayed cell-related toxicity related to the use of MSCs [117]. A further study of I.V autologous MSCs transplantation involving 52 patients (MSC group $[\mathrm{n}=16]$ and the control group [ $\mathrm{n}=36]$ ) demonstrated longterm (up to 5 years) safety and efficacy as well as long-term functional outcome and survival [123]. A recently concluded study has demonstrated that intra-arterial bone marrow mononuclear cell transplantation is feasible and safe in patients both in the acute and sub-acute phase $(>3$ and $<90$ days) of ischaemic cerebral infarct involving the middle cerebral artery territory [124]. There were no reported complication or adverse events during the procedure. An unblinded study [125] on 12 patients with ischaemic stroke that administered intravenous autologous mesenchymal stem cells 36-133 days after onset of stroke demonstrated the feasibility and safety of transplantation of autologous hMSCs expanded in autologous human serum in stroke patients. This is in contrast to the study that used autologous MSCs expanded in foetal calf serum [117]. There were no observed abnormal cell growths or malignancy and no reported complications like neurological deterioration, infections or venous thromboembolism [125]. More clinical trials are currently underway to further evaluate the safety, feasibility and tolerance of autologous bone marrow stem cells in ischaemic stroke patients (Table 3) [126].

\section{CHALLENGES OF TRANSLATING PRECLINICAL STUDIES TO CLINICAL TRIALS}

Stem cell therapy holds great promise as a novel therapeutic approach for stroke, but there are still some challenges in translating results from animal studies to the clinical setting. These include consideration of patient selection in terms patient variables (e.g. age, gender, underlying conditions), anatomical location, size and type of stroke, optimum timing of treatment relative to when the patient's stroke occur, the appropriate choice of cell type and source (human or animal; embryonic, fetal or adult; from brain or other tissues), the route of delivery, translation of dosing with cell survival and the need for immunosuppression, and tracking of stem cells $(66,127-$ 129). The transplantation of cells between- and withinspecies is faced with problems such as rejection, risk of malignancy and ethical considerations [130]. Recent development of techniques to generate ES-like cells via epigenetic reprogramming, termed "iPS cells" [131], opens the potential for autologous neural cell therapy, thereby 
Table 3. Some Complete and On-Going Clinical Trials of Exogenous Stem Cell Therapy

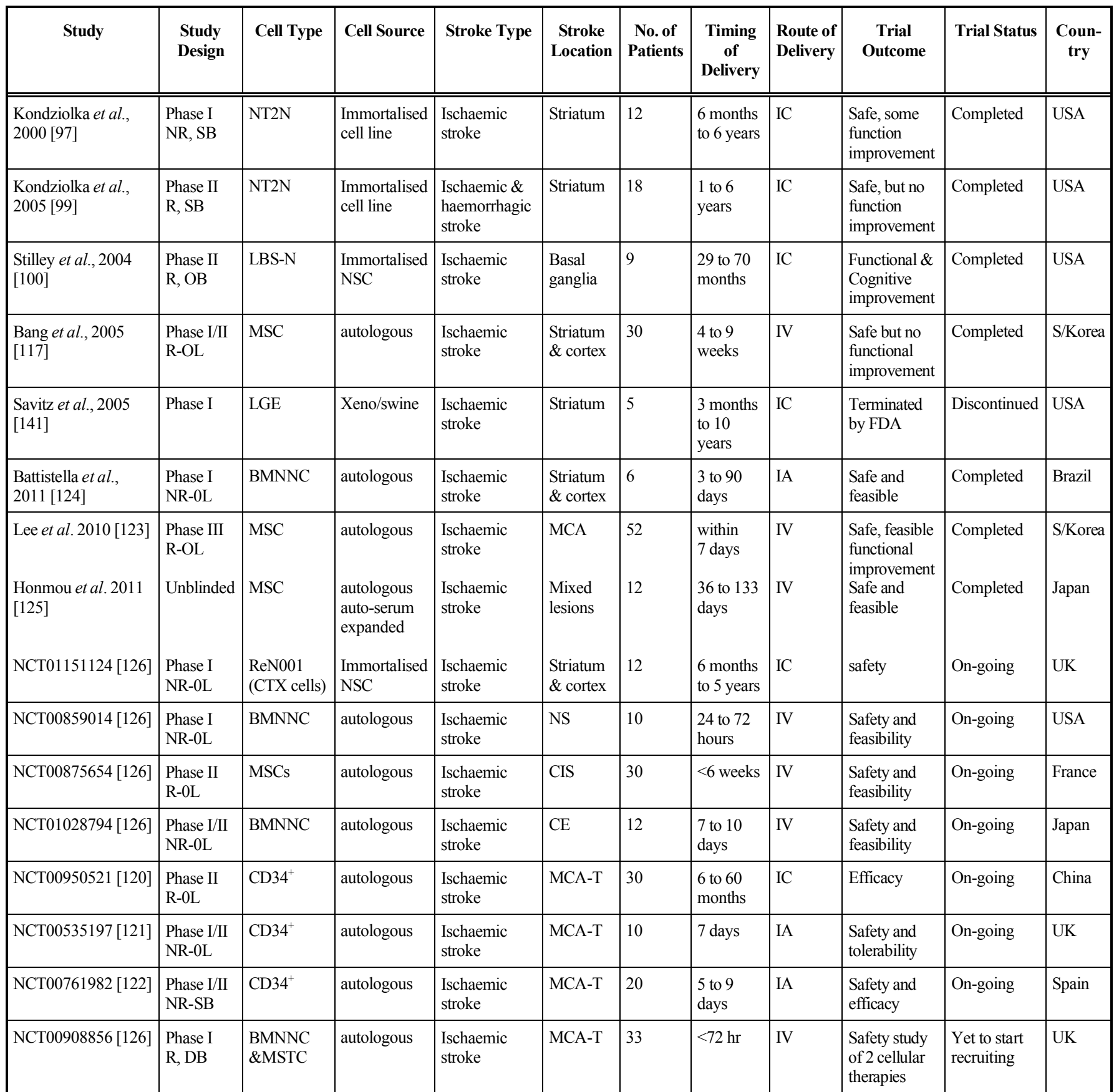

$\mathrm{NR}=$ Nonrandomised, $\mathrm{R}=$ Randomized, $\mathrm{OL}=$ Open labelled, $\mathrm{SB}=$ Single blinded, $\mathrm{MSTC}=$ Marrow stromal cells, CIS $=$ Carotid Ischaemic Stroke, $\mathrm{CE}=\mathrm{Cerebral}$ embolism, NS $=$ not specified, MCA-T $=$ Middle cerebral artery territory, TACS $=$ Total Anterior circulation. IC $=$ Intracerebral, IV=Intravenous, IA=Intraarterial

avoiding the need for immunosuppression. A recent preclinical study suggests that human iPSCs survive and improve recovery in a rat model of stroke, acting both to increase angiogenesis and through neuronal differentiation [132]. Nevertheless, there are currently no clinical trials using iPS cells in stroke treatment. Safety concerns regarding the viral constructs used to reprogram iPS cells are being mitigated by the development of transient transfection techniques that leave cells genetically unaltered after reprogramming $[133,134]$. The production of virus-free iPSCs will address a critical safety concern for the potential use of iPSCs in regenerative medicine [135].
The effect of aging on neurogenesis and the response to stroke requires further study, as a large proportion of research has been carried out in young adult rodents [136]. Robust post-stroke neurogenesis has been observed in aged animals and humans following both endogenous and exogenous stem cell therapies $[137,138]$, suggesting that the stem cell based treatment is suitable for clinical stroke therapy as more than $80 \%$ stroke patients are the elderly $[136,139,140]$. These fundamental issues are critical for any transplantation success and would have to be addressed by scientists, industry partners and clinicians before the reality of such a therapy can be achieved for safe and effective use in the clinical setting. Hence the guidelines from both the 
original STEPS (Stem Cell Therapies as an Emerging Paradigm in Stroke) and the recent STEPS II are set up to help with the fundamental problems [127, 128].

\section{CONCLUSION}

Despite encouraging results in using stem cell transplantation in experimental models of stroke, which have given evidence of significant functional benefits, translation to the clinical settings is still at an early stage. Conclusions about the efficacy of the different treatments used so far in humans are difficult to draw due to the small sample sizes used for the different trials. Although promising, cell transplantation for stroke treatment in humans is still in its infancy and there remains a need for much more work before it becomes a viable therapeutic approach to stroke.

\section{ABBREVIATIONS}

$\begin{array}{ll}\text { AXIS } & =\text { Ax200(G-CSF) for the treatment of ischemic } \\ \text { stroke } & \\ \text { BDNF } & =\text { Brain-derived neurotrophic factor } \\ \text { BMSCs } & =\text { Bone marrow-derived stem cells } \\ \text { CNS } & =\text { Central nervous system } \\ \text { EGF } & =\text { Epidermal growth factor } \\ \text { FGF2 } & =\text { Fibroblast growth factor } 2 \\ \text { HGF } & =\text { Hepatocyte growth factor } \\ \text { HSCs } & =\text { Haematopoietic stem cells } \\ \text { ES } & =\text { Embryonic stem cell } \\ \text { FDA } & =\text { Food and drug administration } \\ \text { G-CSF } & =\text { Granulocyte colony stimulating factor } \\ \text { GIST } & =\text { G-CSF in ischaemic stroke trial } \\ \text { GNDF } & =\text { Glial cell line derived neurotrophic factor } \\ \text { IGF } & =\text { Insulin like growth factor } \\ \text { MCAO } & =\text { Middle cerebral artery occlusion } \\ \text { MSCs } & =\text { Mesenchymal stem cells } \\ \text { NPCs } & =\text { Neutral progenitor cells } \\ \text { PD } & =\text { Parkinson's disease } \\ \text { PISCES } & =\text { The pilot investigation of stem cells in stroke } \\ \text { study } & =\text { Stem cell therapies as an emerging paradigm in } \\ \text { STEPS } & \text { stroke } \\ \text { VEGF }=\text { Vascular endothelial growth factor }\end{array}$

\section{CONFLICT OF INTEREST}

The authors confirm that this article content has no conflict of interest.

\section{ACKNOWLEDGEMENTS}

The authors were supported by funds Oxford University Hospitals NHS Trust (JSB), Parkinson's UK (RAF), and The Henry Smith charity (RC).

\section{REFERENCES}

[1] Di Carlo, A. Human and economic burden of stroke. Age Ageing, 2009, 38, 4-5.

[2] Roger, V.L.; Go, A.S.; Lloyd-Jones, D.M.; Benjamin, E.J.; Berry, J.D.; Borden, W.B.; Bravata, D.M.; Dai, S.; Ford, E.S.; Fox, C.S.; Fullerton, H.J.; Gillespie, C.; Hailpern, S.M.; Heit, J.A.; Howard, V.J.; Kissela, B.M.; Kittner, S.J.; Lackland, D.T.; Lichtman, J.H.; Lisabeth, L.D.; Makuc, D.M.; Marcus, G.M.; Marelli, A.; Matchar, D.B.; Moy, C.S.; Mozaffarian, D.; Mussolino, M.E.; Nichol, G.; Paynter, N.P.; Soliman, E.Z.; Sorlie, P.D.; Sotoodehnia, N.; Turan, T.N.; Virani, S.S.; Wong, N.D.; Woo, D.; Turner, M.B.; American Heart Association Statistics Committee and Stroke Statistics Subcommittee. American Heart Association Statistics Committee and Stroke Statistics Subcommittee. Executive summary: heart disease and stroke statistics--2012 update: a report from the American Heart Association. Circulation, 2012, 125(1), 188-197.

[3] Wardlow, J.M.; Murray, V.; Berge, E.; del Zoppo, G.J. Thrombolysis for acute ischaemic stroke. Cochrane Database Syst. Rev., 2009, 4, CDOOO213.

[4] Hacke, W.; Kaste, M.; Bluhmki, E.; Brozman, M.; Dávalos, A.; Guidetti, D.; Larrue, V.; Lees, K.R.; Medeghri, Z.; Machnig, T.; Schneider, D.; von Kummer, R.; Wahlgren, N.; Toni, D.; ECASS Investigators. Thrombolysis with alteplase 3 to 4.5 hours after acute ischaemic stroke. N. Engl. J. Med., 2008, 359, 1317-1329.

[5] Adams, H.P., Jr.; del, Z.G.; Alberts, M.J.; Bhatt, D.L.; Brass, L.; Furlan, A.; Grubb, R.L.; Higashida, R.T.; Jauch, E.C.; Kidwell, C.; Lyden, P.D.; Morgenstern, L.B.; Qureshi, A.I.; Rosenwasser, R.H.; Scott, P.A.; Wijdicks, E.F.; American Heart Association; American Stroke Association Stroke Council; Clinical Cardiology Council; Cardiovascular Radiology and Intervention Council; Atherosclerotic Peripheral Vascular Disease and Quality of Care Outcomes in Research Interdisciplinary Working Groups. Guidelines for the early management of adults with ischemic stroke: a guideline from the American Heart Association/American Stroke Association Stroke Council, Clinical Cardiology Council, Cardiovascular Radiology and Intervention Council, and the Atherosclerotic Peripheral Vascular Disease and Quality of Care Outcomes in Research Interdisciplinary Working Groups. Stroke, 2007, 38, 1655-1711.

[6] Sandercook, P.A.G.; Council, C.; Gubitz, G.J.; Tseng, M.C. Antiplatelet therapy for acute ischaemic stroke. Cochrane Database Syst. Rev., 2008, 3, CD000029.

[7] Stroke Unit Trialist' Collaboration Organised inpatient (stroke unit) care for stroke. Cochrane Database Syst. Rev., 2007, 4, CD000197. Balami, J.S.; Chen, R.L.; Grunwald, I.Q.; Buchan, A.M. Neurological complications of acute ischaemic stroke. Lancet Neurol., 2011, 10(4), 357-371.

[9] Wade, D.T.; Hewer, R.L. Motor loss and swallowing difficulty after stroke: frequency, recovery, and prognosis. Acta Neurol. Scand., 1987, 76(1), 50-54.

[10] Lawrence, E.S.; Coshall, C.; Dundas, R.; Stewart, J.; Rudd, A.G.; Howard, R.; Wolfe, C.D. Estimates of the Prevalence of Acute Stroke Impairments and Disability in a Multiethnic Population. Stroke, 2001, 32, 1279-1284.

[11] Herman, B.; Leyten, A.C.; van Luijk, J.H.; Frenken, C.W.; Op de Coul, A.A.; Schulte, B.P. Epidemiology of stroke in Tilburg, the Netherlands. The population-based stroke incidence register: 2 . Incidence, initial clinical picture and medical care, and three-week case fatality. Stroke, 1982, 13(5), 629-634.

[12] Reynolds, B.A.; Weiss, S. Generation of neurons and astrocytes from isolated cells of the adult mammalian central nervous system. Science, 1992, 255, 1707-1710.

[13] Erikson, P.S.; Perfilieva, E.; Bjork-Eriksson, T.; Alborn, A.M.; Nordborg, C.; Peterson, D.A.; Gage, F.H. Neurogenesis in the adult human hippocampus. Nat. Med., 1998, 4, 1313-1317.

[14] Curtis, M.A.; Karr, M.; Nannmark, U.; Anderson, M.F.; Axell, M.Z.; Wikkelso, C.; Holtås, S.; van Roon-Mom, W.M.; BjörkEriksson, T.; Nordborg, C.; Frisén, J.; Dragunow, M.; Faull, R.L.; Eriksson, P.S. Human neuroblasts migrate to the olfactory bulb via a lateral ventricular extension. Science, 2007, 315, 1243-1249.

[15] Jin, K.; Wang, X.; Xie, L.; Mao, X.O.; Zhu, W.; Wang, Y.; Shen, J.; Mao, Y.; Banwait, S.; Greenberg, D.A. Evidence for stroke induced neurogenesis in the human brain. Proc. Natl. Acad. Sci. USA, 2006, 103, 13198-13202. 
[16] Arvidsson, A.; Collin, T.; Kirik, D.; Kokaia, Z.; Lindvall, O. Neuronal replacement from endogenous precursors in the adult brain after stroke. Nat. Med., 2002, 8, 963-970.

[17] Nakatomi, H.; Kuriu, T.; Okabe, S.; Yamamoto, S.; Hatano, O.; Kawahara, N.; Tamura, A.; Kirino, T.; Nakafuku, M. Regeneration of hippocampal pyramidal neurons after ischemic brain injury, by recruitment of endogenous neural progenitors. Cell, 2002, 110, 429-441.

[18] Teramoto, T.; Qiu, J.; Plumier, J.C.; Moskowitz, M.A. EGF amplifies the replacement of parvalbumin-expressing striatal interneurons after ischemia. J. Clin. Invest., 2003, 111, 1125-1132.

[19] Uzun G, Subhani D, Amor S. Trophic factors and stem cells for promoting recovery in stroke. J. Vasc. Interv. Neurol., 2010, 3(1), 3-12.

[20] Dobrossy, M.; Busse, T.; Piroth, A.; Rosser, S. Dunnett, and Nikkhah G. Neurorehabilitation with neural transplantation. Neurorehabil. Neural Repair, 2010, 24(8), 692-701.

[21] Chen, R.L.; Nagel, S.; Papadakis, M.; Bishop, T.; Pollard, P.; Ratcliffe, P.J.; Pugh, C.W.; Buchan, A.M. Roles of Individual Prolyl-4-Hydroxylase Isoforms (PHD1-3) in the First 24 Hours Following Transient Focal Cerebral Ischaemia: Insights from Genetically Modified Mice. J. Physiol., 2012, 590(Pt 16), 40794091.

[22] Dharmasaroja, P. Bone marrow-derived mesenchymal stem cells for the treatment of ischemic stroke. J. Clin. Neurosci., 2008, 16, $12-20$.

[23] Zhang, Z.G.; Chopp, M. Neurorestorative therapies for stroke: underlying mechanisms and translation to the clinic. Lancet Neurol., 2009, 8(5), 491-500.

[24] Horie, N.; Pereira, M.P.; Niizuma, K.; Sun, G.; Keren-Gill, H.; Encarnacion, A.; Shamloo, M.; Hamilton, S.A.; Jiang, K.; Huhn, S.; Palmer, T.D.; Bliss, T.M.; Steinberg, G.K. Transplanted stem cell-secreted vascular endothelial growth factor effects poststroke recovery, inflammation, and vascular repair. Stem Cells, 2011, 29(2), 274-285.

[25] Brazelton, T.R.; Rossi, F.M.V.; Keshet, G.I.; Blau, H.E. From marrow to brain: expression of neuronal phenotypes in adult mice. Science, 2000, 290, 1775-1779.

[26] Chen, J.; Li, Y.; Katakowski, M.; Chen, X.; Wang, L.; Lu, D.; Lu, M.; Gautam, S.C.; Chopp, M. Intravenous bone marrow stromal cell therapy reduces apoptosis and promotes endogenous cell proliferation after stroke in female rat. J. Neurosci. Res., 2003, 73, 778-786.

[27] Chen, J.; Shehadah, A.; Pal, A.; Zacharek, A.; Cui, X.; Cui, Y.; Roberts, C.; Lu, M.; Zeitlin, A.; Hariri, R.; Chopp, M. Neuroprotective Effect of Human Placenta-derived Cell Treatment of Stroke in Rats. Cell Transplant., 2012, in press.

[28] Lee, S.T.; Chu, K.; Jung, K.H.; Kim, S.J.; Kim, D.H.; Kang, K.M.; Hong, N.H.; Kim, J.H.; Ban, J.J.; Park, H.K.; Kim, S.U.; Park, C.G.; Lee, S.K.; Kim, M.; Roh, J.K. Anti-inflammatory mechanism of intravascular neural stem cell transplantation in haemorrhagic stroke. Brain, 2008, 131(Pt 3), 616-629.

[29] Shen, C.C.; Lin, C.H.; Yang, Y.C.; Chiao, M.T.; Cheng, W.Y.; Ko, J.L. Intravenous implanted neural stem cells migrate to injury site, reduce infarct volume, and improve behavior after cerebral ischemia. Curr. Neurovasc. Res., 2010, 7(3), 167-179.

[30] Walker, P.A.; Harting, M.T.; Jimenez, F.;, Shah, S.K.; Pati, S.; Dash, P.K.; Cox, C.S., Jr. Direct intrathecal implantation of mesenchymal stromal cells leads to enhanced neuroprotection via an NFkappaB-mediated increase in interleukin-6 production. Stem. Cells Dev., 2010, 19(6), 867-876.

[31] Li, Y.; Chen, J.; Zhang, C.L.; Wang, L.; Lu, D.; Katakowski, M.; Gao, Q.; Shen, L.H.; Zhang, J.; Lu, M.; Chopp, M. Gliosis and brain remodeling after treatment of stroke in rats with marrow stromal cells. Glia, 2005, 49, 407-417.

[32] Shen, L.H.; Li, Y.; Chen, J.; Zhang, J.; Vanguri, P.; Borneman, J.; Chopp, M. Intracarotid transplantation of bone marrow stromal cells increases axon-myelin remodelling after stroke. Neuroscience, 2006, 137, 393-399.

[33] Parr, A.M.; Tator, C.H.; Keating, A. Bone marrow-derived mesenchymal stromal cells for the repair of central nervous system injury. Bone Marrow Transplant., 2008, 40, 609-619.

[34] Andres, R.H.; Horie, N.; Slikker, W.; Keren-Gill, H.; Zhan, K.; Sun, G.; Manley, N.C.; Pereira, M.P.; Sheikh, L.A.; McMillan, E.L.; Schaar, B.T.; Svendsen, C.N.; Bliss, T.M.; Steinberg, G.K. Human neural stem cells enhance structural plasticity and axonal transport in the ischaemic brain. Brain, 2011, 134(Pt 6), 17771789.

[35] Borlongan. C.V.; Lind, J.G.; Dillon-Carter, O.; Yu, G.; Hadman, M.; Cheng, C.; Carroll, J.; Hess, D.C. Intracerebral xenografts of mouse bone marrow cells in adult rats facilitate restoration of cerebral blood flow and blood-brain barrier. Brain Res., 2004, 1009, 26-33.

[36] Shen, L.H.; Li, Y.; Chen, J.; Zacharek, A.; Gao, Q.; Kapke, A.; Lu, M.; Raginski, K.; Vanguri, P.; Smith, A.; Chopp, M. Therapeutic benefit of bone marrow stromal cells administered 1 month after stroke. J. Cereb. Blood Flow Metab., 2007, 27, 6-13.

[37] Wakabayashi, K.; Nagai, A.; Sheikh, A.M.; Shiota, Y.; Narantuya, D.; Watanabe, T.; Masuda, J.; Kobayashi, S.; Kim, S.U.; Yamaguchi, S. Transplantation of human mesenchymal stem cells promotes functional improvement and increased expression of neurotrophic factors in a rat focal cerebral ischemia model. $J$. Neurosci. Res., 2010, 88(5), 1017-1025.

[38] Li, J.; Zhu, H.; Liu, Y.; Li, Q.; Lu, S.; Feng, M.; Xu, Y.; Huang, L.; Ma, C.; An, Y.; Zhao, R.C.; Wang, R.; Qin, C. Human mesenchymal stem cell transplantation protects against cerebral ischemic injury and upregulates interleukin-10 expression in Macacafascicularis. Brain Res., 2010, 1334, 65-72.

[39] Chekhonin, V.P.; Lebedev, S.V.; Volkov, A.I.; Pavlov, K.A.; TerArutyunyants, A.A.; Volgina, N.E.; Savchenko, E.A.; Grinenko, N.F.; Lazarenko, I.P. Activation of expression of brain-derived neurotrophic factor at the site of implantation of allogenic and xenogenic neural stem (progenitor) cells in rats with ischemic cortical stroke. Bull. Exp. Biol. Med., 2011, 150(4), 515-518.

[40] Louissaint, Jr., A.; Rao, S.; Leventhal, C.; Goldman, S.A. Coordinated interaction of neurogenesis and angiogenesis in the adult songbird brain. Neuron, 2002, 34, 945-960.

[41] Chen, J.; Chopp, M. Neurorestorative treatment of stroke: cell and pharmacological approaches. NeuroRX, 2006, 3, 466-473.

[42] Chopp, M.; Li, Y. Treatment of neural injury with marrow stromal cells. Lancet Neurol., 2002, 1(2), 92-100.

[43] Wechsler, L.R.; Kondziolka, D. Cell therapy: replacement. Stroke, 2003, 34(8), 2081-2082.

[44] Doeppner, T.R.; Hermann, D.M. Mesenchymal stem cells in the treatment of ischemic stroke: progress and possibilities. Stem Cells Cloning Adv. Appl., 2010, 3, 157-163.

[45] Hess, D.C.; Hill, W.D.; Carroll, J.E.; Borlongan, C.V. Do bone marrow cells generate neurons? Arch. Neurol., 2004, 61, 483-485.

[46] Haas, S.; Weidner, N.; Winkler, J. Adult stem cell therapy in stroke. Curr. Opin. Neurol., 2005, 18, 59-64.

[47] Borlongan, C.V.; Hess, D.C. New hope for stroke patients: mobilization of endogenous stem cells. Can. Med. Assoc. J., 2006, 174(7), 954-955.

[48] Young, C.C.; Brooks, K.J.; Buchan, A.M.; Szele, F.G. Cellular and molecular determinants of stroke-induced changes in subventricular zone cell migration. Antioxidants Redox. Signal., 2011, 14(10), 1877-1888.

[49] Wiltrout, C.; Lang, B.; Yan, Y.; Dempsey, R.J.; Vemuganti, R. Repairing brain after stroke: A review on post-ischemic neurogenesis. Neurochem. Int., 2007, 50, 1028-1041.

[50] Schäbitz, W.R.; Schneider, A. New targets for established proteins: exploring G-CSF for the treatment of stroke. Trends. Pharmacol. Sci., 2007, 28(4), 157-161.

[51] Schneider, A.; Kruger, I.C.; Steigleder, I.T.; Weber, D.; Pitzer, C.; Laage, R.; Aronowski, J.; Maurer, M.H.; Gassler, N.; Mier, W.; Hasselblatt, M.; Kollmar, R.; Schwab, S.; Sommer, C.; Bach, A.; Kuhn, H.G.; Schäbitz, W.R. The hematopoietic factor G-CSF is a neuronal ligand that counteracts programmed cell death and drives neurogenesis. J. Clin. Invest., 2005, 115, 2083-2098.

[52] Schabitz, W.R.; Kollmar, R.; Schwaninger, M.; Juettler, E.; Bardutzky, J.; Schölzke, M.N.; Sommer, C.; Schwab, S. Neuroprotective effect of granulocyte colony-stimulating factor after focal cerebral ischemia. Stroke, 2003, 34, 745-751.

[53] Shyu, W.C.; Lin, S.Z.; Yang, H.I.; Tzeng, Y.S.; Pang, C.Y.; Yen, P.S.; Li, H. Functional recovery of stroke rats induced by granulocyte colony-stimulating factor-stimulated cells. Circulation, 2004, 110, 1847-1854.

[54] Park, H.K.; Kon Chu, K.; Lee, S.T. Granulocyte colony-stimulating factor induces sensorimotor recovery in intracerebral hemorrhage. Brain Res., 2005, 1041, 125-131.

[55] Gibson, C.L.; Jones, N.C.; Prior, M.J.W.; Bath, P.M.W.; Murphy, S. G-CSF suppresses edema formation and reduces interleukin-1ß 
expression after cerebral ischemia in mice. J. Neuropathol. Exp. Neurol., 2005, 64, 1-7.

[56] Kollmar, R.; Henninger, N.; Urbanek, C.; Schwab, S. G-CSF and rt-PA for the treatment of Experimental Embolic Stroke. Cerebrovasc. Dis., 2007, 23(Suppl 2), 23.

[57] Shyu, W.C.; Lin, S.Z.; Lee, C.C.; Liu, D.D.; Li, H. Granulocyte colony-stimulating factor for acute ischemic stroke: a randomized controlled trial. Can. Med. Assoc. J., 2006, 174, 927-933.

[58] Zhang, J.J.; Deng, M.; Zhang, Y.; Sui, W.; Wang, L.; Sun, A. A short-term assessment of recombinant granulocyte-stimulating factor (RHG-CSF) in treatment of acute cerebral infarction. Cerebrovasc. Dis., 2006, 22, 323.

[59] Conti, J.A.; Scher, H.I. Acute arterial thrombosis after escalateddose methotrexate, vinblastine, doxorubicin, and cisplatin chemotherapy with recombinant granulocyte colony-stimulating factor. A possible new recombinant granulocyte colony-stimulating factor toxicity. Cancer, 1992, 70(11), 2699-2702.

[60] Lindemann, A.; Rumberger, B. Vascular complications in patients treated with granulocyte colony-stimulating factor (G-CSF). Eur. J. Cancer, 1993, 29A, 2338-2339.

[61] Sprigg, N.; Bath, P.M.; Zhao, L.; Willmot, M.R.; Gray, L.J.; Walker, M.F.; Dennis, M.S.; Russell, N. Granulocyte-colonystimulating factor mobilizes bone marrow stem cells in patients with subacute ischemic stroke: the Stem cell Trial of recovery EnhanceMent after Stroke (STEMS) pilot randomized, controlled trial (ISRCTN 16784092). Stroke, 2006, 37(12), 2979-2983.

[62] http://www.clinicaltrials.gov/ Identifier: ISRCTN 63336619.

[63] Schabitz, W.R.; Laage, R.; Vogt, G.; Koch, W.; Kollmar, R.; Schwab, S.; Schneider, D.; Hamann, G.F.; Rosenkranz, M.; Veltkamp, R.; Fiebach, J.B.; Hacke, W.; Grotta, J.C.; Fisher, M.; Schneider, A. AXIS: A Trial of Intravenous Granulocyte ColonyStimulating Factor in Acute Ischemic Stroke. Stroke, 2010, 41(11), 2545-2551.

[64] http://www.clinicaltrials.gov/ Identifier: NCT00927836.

[65] http://www.clinicaltrials.gov/ Identifier: NCT008095.

[66] Bliss, T.M.; Andres, R.H.; Steinberg, G.K. Optimizing the Success of Cell Transplantation Therapy for Stroke. Neurobiol. Dis., 2010, 37(2), 275-283.

[67] Banerjee, S.; Williamson, D.; Habib, N.; Gordon, M.; Chataway, J. Human stem cell therapy in ischaemic stroke: a review. Age Ageing, 2011, 40(1), 7-13.

[68] Wachs, F.P.; Couillard-Despres, S.; Engelhardt, M.; Wilhelm, D.; Ploetz, S.; Vroemen, M.; Kaesbauer, J.; Uyanik, G.; Klucken, J.; Karl, C.; Tebbing, J.; Svendsen, C.; Weidner, N.; Kuhn, H.G.; Winkler, J.; Aigner, L. High efficacy of clonal growth and expansion of adult neural stem cells. Lab. Invest., 2003, 83(7), 949962.

[69] Nunes, M.C.; Roy, N.S.; Keyoung, H.M.; Goodman, R.R.; McKhann, G., 2nd.; Jiang, L.; Kang, J.; Nedergaard, M.; Goldman, S.A. Identification and isolation of multipotential neural progenitor cells from the subcortical white matter of the adult human brain. Nat. Med., 2003, 9, 439-947.

[70] Arsenijevic, Y.:Villemure, J.G.; Bruner, J.F.; Bloch, J.J.; Déglon, N.; Kostic, C.; Zurn, A.; Aebischer, P. Isolation of multipotent neural precursors residing in the cortex of adult brain. Exp. Neurol., 2001, 170, 48-62.

[71] Kitajima, H.; Yoshimura, S.; Kokuzawa, J.; Kato, M.; Iwama, T.; Motohashi, T.; Kunisada, T.; Sakai, N. Culture method for the induction of neurospheres from mouse embryonic stem cells by coculture with PA6 stromal cells. J. Neurosci. Res., 2005, 80, 467474.

[72] O'Shea, K.S. Neural differentiation of embryonic stem cells. Methods Mol. Biol., 2002, 198, 3-14.

[73] Singh, R.N.; Nakano, T.; Xuing, L.; Kang, J.; Nedergaard, M.; Goldman, S.A. Enhancer-specified GFP-based FACS purification of human spinal motor neurons from embryonic stem cells. Exp. Neurol., 2005, 196, 224-234.

[74] Carson, C.T.; Aigner, S.; Gage, F.H. Stem cells: the good, bad and barely in control. Nat. Med., 2006, 12(11), 1237-1238.

[75] Lee, H, J.; Park, I, H.; Kim, H, J.; Kim, S.U. Human neural stem cells overexpressing glial cell line-derived neurotrophic factor in experimental cerebral hemorrhage. Gene Ther., 2009, 16(9), 10661076.

[76] Chen, B.; Gao, X.Q.; Yang, C.X.; Tan, S.K.; Sun, Z.L.; Yan, N.H.; Pang, Y.G.; Yuan, M.; Chen, G.J.; Xu, G.T.; Zhang, K.; Yuan, Q.L. Neuroprotective effect of grafting GDNF gene-modified neural stem cells on cerebral ischemia in rats. Brain Res., 2009, 1284, 1-11.

[77] Bacigaluppi, M.; Pluchino, S.; Peruzzotti-Jametti, L.; Kilic, E.; Kilic, U.; Salani, G.; Brambilla, E.; West, M.J.; Comi, G.; Martino, G.; Hermann, D.M. Delayed post-ischaemic neuroprotection following systemic neural stem cell transplantation involves multiple mechanisms. Brain, 2009, 132(Pt 8), 2239-2251.

[78] Sun, C.; Zhang, H.; Li, J.; Huang, H.; Cheng, H.; Wang, Y.; Li, P.; An, Y. Modulation of the major histocompatibility complex by neural stem cell-derived neurotrophic factors used for regenerative therapy in a rat model of stroke. J. Transl. Med., 2010, 8, 77.

[79] Lee, H.J.; Kim, K.S.; Kim, E.J.; Choi, H.B.; Lee, K.H.; Park, I.H.; Ko, Y.; Jeong, S.W.; Kim, S.U. Brain transplantation of immortalized human neural stem cells promotes functional recovery in mouse intracerebral hemorrhage stroke model. Stem Cells, 2007, 25(5), 1204-1212.

[80] Lee, H.J.; Kim, K.S.; Park, I.H.; Kim, S.U. Human neural stem cells over-expressing VEGF provide neuroprotection, angiogenesis and functional recovery in mouse stroke model. PLoS One, 2007, 2(1), e156.

[81] Martino, G.; Pluchino, S. The therapeutic potential of neural stem cells. Nat. Rev. Neurosci., 2009, 7(5), 395-406.

[82] Cossetti, C.; Alfaro-Cervello, C.; Donegà, M.; Tyzack, G.; Pluchino, S. New perspectives of tissue remodelling with neural stem and progenitor cell-based therapies. Cell Tissue Res., 2012, 349(1), 321-329.

[83] Cusimano, M.; Biziato, D.; Brambilla, E.; Donegà, M.; AlfaroCervello, C.; Snider, S.; Salani, G.; Pucci, F.; Comi, G.; GarciaVerdugo, J.M.; De Palma, M.; Martino, G.; Pluchino, S. Transplanted neural stem/precursor cells instruct phagocytes and reduce secondary tissue damage in the injured spinal cord. Brain, 2012, 135, 447-460.

[84] Erdö, F.; Bührle, C.; Blunk, J.; Hoehn, M.; Xia, Y.; Fleischmann, B.; Föcking, M.; Küstermann, E.; Kolossov, E.; Hescheler, J.; Hossmann, K.A.; Trapp, T. Host-dependent tumorigenesis of embryonic stem cell transplantation in experimental stroke. $J$. Cereb. Blood Flow Metab., 2003, 23(7), 780-785.

[85] Kelly, S.; Bliss, T.M.; Shah, A.K.; Sun, G.H.; Ma, M.; Foo, W.C.; Masel, J.; Yenari, M.A.; Weissman, I.L.; Uchida, N.; Palmer, T.; Steinberg, G.K. Transplanted human fetal neural stem cells survive, migrate, and differentiate in ischemic rat cerebral cortex. Proc. Natl. Acad. Sci. USA, 2004, 101(32), 11839-11844.

[86] Jin, K.; Mao, X.; Xie, L.; Galvan, V.; Lai, B.; Wang, Y.; Gorostiza, O.; Wang, X.; Greenberg, D.A. Transplantation of human neural precursor cells in Matrigel scaffolding improves outcome from focal cerebral ischemia after delayed postischemic treatment in rats. J. Cereb. Blood Flow Metab., 2010, 30(3), 534-544..

[87] Darsalia, V.; Allison, S.J. Cusulin, C.; Monni, E.; Kuzdas, D.; Kallur, T.; Lindvall, O.; Kokaia, Z. Cell number and timing of transplantation determine survival of human neural stem cell grafts in stroke-damaged rat brain. J. Cereb. Blood Flow Metab., 2011, 31(1), 235-242.

[88] Seminatore, C.; Polentes, J.; Ellman, D.; Kozubenko, N.; Itier, V.; Tine, S.; Tritschler, L.; Brenot, M.; Guidou, E.; Blondeau, J.; Lhuillier, M.; Bugi, A.; Aubry, L.; Jendelova, P.; Sykova, E.; Perrier, A.L.; Finsen, B.; Onteniente, B. The postischemic environment differentially impacts teratoma or tumor formation after transplantation of human embryonic stem cell-derived neural progenitors. Stroke, 2010, 41(1), 153-159.

[89] http://www.clinicaltrials.gov/ Identifier: NCT01151124.

[90] Stroemer, P.; Hope, A.; Patel, S.; Pollock, K.; Sinden, J. Development of a human neural stem cell line for use in recovery from disability after stroke. Front. Biosci., 2008, 13, 2290-2292.

[91] Andrews, P.W. Retinoic acid induces neuronal differentiation of a cloned human embryonal carcinoma cell line in vitro. Dev. Biol., 1984, 103, 285-293.

[92] Hara, K. ; Yasuhara, T.; Maki, M. ; Matsukawa, N.; Masuda, T.; Yu, S.J.; Ali, M.; Yu, G.; Xu, L.; Kim, S.U.; Hess, D.C.; Borlongan, C.V. Neural progenitor NT2N cell lines from teratocarcinoma for transplantation therapy in stroke. Prog. Neurobiol., 2008, 85(3), 318-334.

[93] Nishino, H.; Borlongan, C.V. Restoration of function by neural transplantation in the ischemic brain. Prog. Brain Res., 2000, 127, 461-476.

[94] Borlongan, C.V.; Tajima, Y.; Trojanowski, J.Q.; Lee, V.M.; Sanberg, P.R. Transplantation of cryopreserved human embryonal 
carcinoma-derived neurons (NT2N cells) promotes functional recovery in ischemic rats. Exp. Neurol., 1998, 149(2), 310-321.

[95] Saporta, S.; Borlongan, C.V.; Sanberg, P.R. Neural transplantation of human neuroteratocarcinoma (hNT) neurons into ischemic rats. A quantitative dose-response analysis of cell survival and behavioral recovery. Neuroscience, 1999, 91(2), 519-525.

[96] Hara, K.; Matsukawa, N.; Yasuhara, T.; Xu, L.; Yu, G.; Maki, M.; Kawase, T.; Hess, D.C.; Kim, S.U.; Borlongan, C.V. Transplantation of post-mitotic human neuroteratocarcinomaoverexpressing Nurr1 cells provides therapeutic benefits in experimental stroke: in vitro evidence of expedited neuronal differentiation and GDNF secretion. J. Neurosci. Res., 2007, 85(6), 1240-1251.

[97] Kondziolka, D.; Wechsler, L.; Goldstein, S.; Meltzer, C.; Thulborn, K.R.; Gebel, J.; Jannetta, P.; DeCesare, S.; Elder, E.M.; McGrogan, M.; Reitman, M.A.; Bynum, L. Transplantation of cultured human neuronal cells for patients with stroke. Neurology, 2000, 55(4), 565-569.

[98] Nelson, P.T.; Kondziolka, D.; Wechsler, L.; Goldstein, S.; Gebel, J.; DeCesare, S.; Elder, E.M.; Zhang, P.J.; Jacobs, A.; McGrogan, M.; Lee, V.M.; Trojanowski, J.Q. Clonal human (hNT) neuron grafts for stroke therapy: neuropathology in a patient 27 months after implantation. Am. J. Pathol., 2002, 160, 1201-1206.

[99] Kondziolka, D.; Steinberg, G.K.; Wechsler, L.; Meltzer, C.C.; Elder, E.; Gebel, J.; Decesare, S.; Jovin, T.; Zafonte, R.; Lebowitz, J.; Flickinger, J.C.; Tong, D.; Marks, M.P.; Jamieson, C.; Luu, D.; Bell-Stephens, T.; Teraoka, J. Neurotransplantation for patients with subcortical motor stroke: a phase 2 randomized trial. $J$. Neurosurg., 2005, 103(1), 38-45.

[100] Stilley, C.S.; Ryan, C.M.; Kondziolka, D.; Bender, A.; DeCesare, S.; Wechsler, L. Changes in cognitive function after neuronal cell transplantation for basal ganglia stroke. Neurology, 2004, 63(7), 1320-1322.

[101] Mezey, E.; Chandross, K.J.; Harta, G.; Maki, R.A.; McKercher, S.R. Turning blood into brain: cells bearing neuronal antigens generated in vivo from bone marrow. Science, 2000, 290(5497), 1779-1782.

[102] Sonntag, K.C.; Simantov, R.; Kim, K.S.; Isacson, O. Temporally induced Nurrl can induce a non-neuronal dopaminergic cell type in embryonic stem cell differentiation. Eur. J. Neurosci., 2004, 19, 1141-1152.

[103] Kitada, M.; Dezawa, M. Parkinson's disease and mesenchymal stem cells: potential for cell-based therapy. Parkinsons Dis., 2012, 2012, 873706 .

[104] Ying, Q.L.; Nichols, J.; Evans, E.P.; Smith, A.G. Changing potency by spontaneous fusion. Nature, 2002, 416, 545-548.

[105] Terada, N.; Hamazaki, T.; Oka, M.; Hoki, M.; Mastalerz, D.M.; Nakano, Y.; Meyer, E.M.; Morel, L.; Petersen, B.E.; Scott, E.W. Bone marrow cells adopt the phenotype of other cells by spontaneous cell fusion. Nature, 2002, 416, 542-545.

[106] Shyu, W.C.; Lin, S.Z.; Chiang, M.F.; Su, C.Y.; Li, H. Intracerebral peripheral blood stem cell (CD34+) implantation induces neuroplasticity by enhancing beta1 integrin-mediated angiogenesis in chronic stroke rats. J. Neurosci., 2006, 26, 3444-3453.

[107] Taguchi, A.; Soma, T.; Tanaka, H. Kanda, T.; Nishimura, H.; Yoshikawa, H.; Tsukamoto, Y.; Iso, H.; Fujimori, Y.; Stern, D.M.; Naritomi, H.; Matsuyama, T. Administration of CD34+ cells after stroke enhances neurogenesis via angiogenesis in a mouse model. J. Clin. Invest., 2004, 114, 330-338.

[108] Felfly, H.; Muotri, A.; Yao, H.; Haddad, G.G. Hematopoietic stem cell transplantation protects mice from lethal stroke. Exp. Neurol., 2010, 225(2), 284-293.

[109] Pittenger, M.F.; Mackay, A.M.; Beck, S.C.; Jaiswal, R.K.; Douglas, R.; Mosca, J.D.; Moorman, M.A.; Simonetti, D.W.; Craig, S.; Marshak, D.R. Multilineage potential of adult human mesenchymal stem cells. Science, 1999, 284, 143-147.

[110] Brazelton, T.R.; Rossi, F.M.; Keshet, G.I.; Blau, H.M. From marrow to brain: expression of neuronal phenotypes in adult mice. Science, 2000, 290(5497), 1775-1779.

[111] Orlic, D.; Kajstura, J.; Chimenti, S.; Jakoniuk, I.; Anderson, S.M.; Li, B.; Pickel, J.; McKay, R.; Nadal-Ginard, B.; Bodine, D.M.; Leri, A.; Anversa, P. Bone marrow cells regenerate infarcted myocardium. Nature, 2001, 410, 701-705.

[112] Dominici, M.; Le Blanc, K.; Mueller, I.; Slaper-Cortenbach, I.; Marini, F.; Krause, D.; Deans, R.; Keating, A.; Prockop, D.J.; Horwitzm E. Minimal criteria for defining multipotent mesenchymal stromal cells. The International Society for Cellular Therapy position statement. Cytotherapy, 2006, 8(4), 315-317.

[113] Chen, J.; Li, Y.; Wang, L.; Zhang, Z.; Lu, D.; Lu, M.; Chopp, M. Therapeutic benefit of intravenous administration of bone marrow stromal cells after cerebral ischemia in rats. Stroke, 2001, 32, 10051011.

[114] Li, Y.; Chen, J.; Wang, L.; Zhang, Z.; Lu, M.; Chopp, M. Treatment of stroke in rat with intracarotid administration of marrow stromal cells. Neurology, 2001, 56, 1666-1672.

[115] Wakabayashi, K.; Nagai, A.; Sheikh, A.M.; Shiota, Y.; Narantuya, D.; Watanabe, T.; Masuda, J.; Kobayashi, S.; Kim, S.U.; Yamaguchi, S. Transplantation of human mesenchymal stem cells promotes functional improvement and increased expression of neurotrophic factors in a rat focal cerebral ischemia model. $J$. Neurosci. Res., 2010, 88(5), 1017-1025.

[116] Shen, L.H.; Li, Y.; Chen, J.; Zacharek, A.; Gao, Q.; Kapke, A.; Lu, M.; Raginski, K.; Vanguri, P.; Smith, A.; Chopp, M. Therapeutic benefit of bone marrow stromal cells administered 1 month after stroke. J. Cereb. Blood Flow Metab., 2007, 27(1), 6-13.

[117] Bang, O.Y.; Lee, J.S.; Lee, P.H.; Lee, G. Autologous mesenchymal stem cell transplantation in stroke patients. Ann. Neurol., 2005, 57(6), 874-882.

[118] Roitbak, T.; Li, L.; Cunningham, L.A. Neural stem/progenitor cells promote endothelial cell morphogenesis and protect endothelial cells against ischemia via HIF-1alpha-regulated VEGF signalling. J. Cereb. Blood Flow Metab., 2008, 28, 1530-1542.

[119] Lin, S.Z.; Shyu, W.C.; L, i H. CD34+ stem cell therapy in chronic stroke patients- Phase 1 trial. Cell Transplant., 2008, 17(4), 472.

[120] http://www.clinicaltrials.gov/ Identifier: NCT00950521

[121] http://www.clinicaltrials.gov/ Identifier: [NCT00535197 [7 days].

[122] http://www.clinicaltrials.gov/ Identifier: NCT00761982 [5-9days].

[123] Lee, J.S.; Hong, J.M.; Moon, G.J.; Lee, P.H.; Ahn, Y.H.; Bang, O.Y. STARTING collaborators. A long-term follow-up study of intravenous autologous mesenchymal stem cell transplantation in patients with ischemic stroke. Stem Cells, 2010, 28(6), 1099-1106.

[124] Battistella, V.; de Freitas, G.R.; da Fonseca, L.M.; Mercante, D.; Gutfilen, B.; Goldenberg, R.C.; Dias, J.V.; Kasai-Brunswick, T.H.; Wajnberg, E.; Rosado-de-Castro, P.H.; Alves-Leon, S.V.; MendezOtero, R.; Andre, C. Safety of autologous bone marrow mononuclear cell transplantation in patients with nonacute ischemic stroke. Regen. Med., 2011, 6(1), 45-52.

[125] Honmou, O.; Houkin, K.; Matsunaga, T.; Niitsu, Y.; Ishiai, S.; Onodera, R.; Waxman, S.G.; Kocsis, J.D. Intravenous administration of auto serum-expanded autologous mesenchymal stem cells in stroke. Brain, 2011, 134(Pt 6), 1790-1807.

[126] (http://www.clinicaltrials.gov/ Identifier: NCT00859014, NCT01151124, NCT00875654, NCT01028794, NCT00908856.

[127] Stem Cell Therapies as an Emerging Paradigm in Stroke (STEPS): Bridging Basic and Clinical Science for Cellular and Neurogenic Factor Therapy in Treating Stroke. The STEPS Participants Stroke, 2009, 40, 510-515.

[128] Savitz, S.I.; Chopp, M.; Deans, R.; Carmichael, S.T.; Phinney, D.; Wechsler, L. Stem cell therapy as an emerging paradigm for stroke (STEPS) II. Stroke, 2011, 42(3), 825-829.

[129] Boncoraglio, G.B.; Bersano, A.; Candelise, L.; Reynolds, B.A.; Parati, E.A. Stem cell transplantation for ischemic stroke. Cochrane Database Syst. Rev., 2010, 9, CD007231.

[130] Weissman, I.L. Stem cells-scientific, medical and political issues. N. Engl. J. Med., 2002, 346, 1576-1579.

[131] Takahashi, K.; Yamanaka, S. Induction of pluripotent stem cells from mouse embryonic and adult fibroblast cultures by defined factors. Cell, 2006, 126(4), 663-676.

[132] Oki, K.; Tatarishvili, J.; Wood, J.; Koch, P.; Wattananit, S.; Mine, Y.; Monni, E.; Tornero, D.; Ahlenius, H.; Ladewig, J.; Brüstle, O.; Lindvall, O.; Kokaia, Z. Human-induced pluripotent stem cells form functional neurons and improve recovery after grafting in stroke-damaged brain. Stem Cells, 2012, 30(6), 1120-1133.

[133] Woltjen. K.; Michael, I.P.; Mohseni, P.; Desai, R.; Mileikovsky, M.; Hämäläinen, R.; Cowling, R.; Wang, W.; Liu, P.; Gertsenstein, M.; Kaji, K.; Sung, H.K.; Nagy, A. piggyBac transposition reprograms fibroblasts to induced pluripotent stem cells. Nature, 2009, 458, 766-770.

[134] Yusa, K.; Rad, R.; Takeda, J.; Bradley, A. Generation of transgenefree induced pluripotent mouse stem cells by the piggyBac transposon. Nat. Methods, 2009, 6(5), 363-369. 
[135] Okita, K.; Nakagawa, M.; Hyenjong, H.; Ichisaka, T.; Yamanaka, S. Generation of mouse induced pluripotent stem cells without viral vectors. Science, 2008, 322, 949-953.

[136] Chen, R.L.; Balami, J.; Esiri, M.; Chen, L.H.; Buchan, A.M. Stroke in ageing: an overview of evidence. Nat. Rev. Neurol., 2010, 6, 256-265.

[137] Ahlenius, H.; Visan, V.; Kokaia, M.; Lindvall, O.; Kokaia, Z. Neural stem and progenitor cells retain their potential for proliferation and differentiation into functional neurons despite lower number in aged brain. J. Neurosci., 2009, 29, 4408-4419.

[138] Jin, K.; Mao, X.; Xie, L.; Greenberg, R.B.; Peng, B.; Moore, A.; Greenberg, M.B.; Greenberg, D.A. Delayed transplantation of human neural precursor cells improves outcome from focal cerebral ischemia in aged rats. Aging Cell, 2010, 9(6), 1076-1083.

[139] Swaab, D.F.; Dubelaar, E.J.; Hofman, M.A.; Scherder, E.J.; van Someren, E.J.; Verwer, R.W. Brain aging and Alzheimer's disease; use it or lose it. Prog. Brain Res., 2002, 138, 343-373.

[140] Abdipranoto, A.; Wu, S.; Stayte, S.; Vissel, B. The role of neurogenesis in neurodegenerative diseases and its implications for therapeutic development. CNS Neurol. Dis. Drug Targets, 2008, 7, 187-210.

[141] Savitz, S.I.; Dinsmore, J.; Wu, J.; Henderson, G.V.; Stieg, P.; Caplan, L.R. Neurotransplantation of fetal porcine cells in patients with basal ganglia infarcts: a preliminary safety and feasibility study. Cerebrovasc. Dis., 2005, 20(2), 101-107. 